\title{
A Simple and Fast Procedure for in situ Determination of Water in Ethanol Fuel
}

\author{
Mauricio S. Ribeiro, ${ }^{a}$ Lúcio Angnes ${ }^{a}$ and Fábio R. P. Rocha ${ }^{*, b}$ \\ ${ }^{a}$ Instituto de Química, Universidade de São Paulo, CP 26077, 05508-000 São Paulo-SP, Brazil \\ ${ }^{b}$ Centro de Energia Nuclear na Agricultura, Universidade de São Paulo, \\ CP 96, 13400-970 Piracicaba-SP, Brazil
}

\begin{abstract}
Um procedimento simples e de baixo custo, baseado na elevada diferença de solubilidade de cloreto de sódio em etanol e em água, é proposto para a estimativa do teor de água em etanol combustível. A concentração iônica de soluções saturadas com o sal é monitorada por medidas de condutividade com resposta linear até $16 \%$ de água em meio alcoólico e limite de detecção de $0,05 \%(\mathrm{v} / \mathrm{v})$. O procedimento é preciso (coeficiente de variação de $0,6 \%, \mathrm{n}=10$ ) e exato (resultados concordantes com os obtidos por titulação amperométrica de Karl Fischer com 95\% de confiança). Um dispositivo eletrônico que explora o mesmo princípio foi proposto para monitoramento in situ de etanol combustível visando à detecção rápida de não conformidades. O dispositivo pode ser operado por não especialistas, gerando uma resposta binária indicada por LEDs coloridos e foi usado com sucesso na classificação de amostras comerciais adulteradas com diferentes quantidades de água.
\end{abstract}

A simple and inexpensive procedure, based on the high difference in solubility of sodium chloride in ethanol and water, is proposed to estimate the water content in ethanol fuel. The ionic concentration of solutions saturated with the salt is monitored by conductometric measurements with a linear response up to $16 \%$ water in an alcoholic medium and a limit of detection of $0.05 \%(\mathrm{v} / \mathrm{v})$. The procedure is precise (coefficient of variation of $0.6 \%, \mathrm{n}=10$ ) and accurate (results in agreement with those obtained by Karl Fischer amperometric titration at the $95 \%$ confidence level). An indicating electronic device exploiting the same principle was proposed for in situ monitoring of ethanol fuel samples aiming at the fast detection of unconformities. The device can be operated by nonexperts, generating a binary response indicated by coloured LEDs, and it successfully classified commercial samples spiked with different amounts of water.

Keywords: ethanol fuel, water, in situ analysis, conductivity

\section{Introduction}

The search for renewable and less polluting sources of energy is one of the major global challenges and, in this context, the replacement of fossil fuels is essential. Ethanol, obtained by the fermentation of sugar from vegetable sources such as sugar cane, is a real alternative because it can be obtained from renewable sources and its production and consumption as a fuel are less polluting than petroleum derivatives. The annual world production of ethanol reached ca. 85 billion litres in 2011 and 2012, ${ }^{1}$ being estimated that ca. $70 \%$ of which is consumed as fuel. Brazil produces ca. 27 billion litres per year, ${ }^{2}$ being the pioneer country in the production and use of ethanol fuel.

*e-mail: frprocha@cena.usp.br
Despite the use of hydrated ethanol fuel being restricted to Brazil, anhydrous ethanol is used in mixtures with gasoline in Europe and other countries such as the USA, Mexico, India, Argentina and Japan. The consumption of ethanol has increased with the use of flexible fuel vehicles that can work on gasoline and ethanol, as well as the increase in costs of petroleum derivatives and general political and environmental aspects. The costs related to the production of ethanol were four fold reduced in the last two decades due to large scale sugar cane culture and technological innovations. ${ }^{3}$ Nowadays, the production costs are competitive with those of gasoline and other petroleum derivatives.

Some parameters of quality need to be considered to assure the performance of ethanol fuel, as well as to avoid deleterious effects to motors and to reduce the emission of 
pollutants. According to the Brazilian Petroleum Agency (ANP), hydrated ethanol fuel needs to contain within 95.1 and $96.0 \%$ (v/v) ethanol, ${ }^{4}$ which corresponds to a maximum water content of $4.9 \%$ (v/v). Sample analyses are usually carried out in laboratories, resulting in relatively high costs and the delayed emission of results in comparison to the fuel consumption. The time consuming procedures are incompatible with the high fuel demand, making it difficult to detect unconformities. The water content in the fuel is the main parameter to be controlled in order to avoid adulterations. It can be determined, for example, by density measurements ${ }^{5}$ or in the laboratory by the Karl Fischer titration. ${ }^{6}$ Although density measurement is a fast alternative, it is not specific for water and the results can be masked by the presence of additives used to change the physical chemical characteristics in adulterated samples. The Karl Fischer method has been widely applied for water determination in several matrices. However, despite the development of automated procedures, ${ }^{7,8}$ the analysis is time consuming and yields large amounts of waste, which are critical aspects for large-scale monitoring. Other ingenious alternatives, such as flow injection enthalpimetry ${ }^{9}$ and near infrared spectrometry, ${ }^{10}$ are still unsuitable for in situ measurements. Procedures to this aim should be simple, robust, fast and only require portable instrumentation, as recently demonstrated for the determination of free glycerol in biodiesel. ${ }^{11}$

In this work, a simple and fast procedure based on measurements of the electric conductivity of samples previously saturated with an inorganic salt is proposed for the determination of the water content of ethanol fuel. A reliable and low cost instrument was also developed for in situ monitoring of this parameter in fuel supply stations.

\section{Experimental}

\section{Apparatus}

Preliminary measurements were carried out with a conductivity meter (Micronal B330) coupled to a conductivity cell (Analyser 7A04). Sample and reference solutions saturated with the inorganic salts were maintained under magnetic stirring in a cell with the temperature controlled at $25.0 \pm 0.1{ }^{\circ} \mathrm{C}$. Graduated $15 \mathrm{~mL}$ polypropylene vessels were used for the preparation of samples and reference solutions. A Karl Fischer automatic titrator (Metrohm 787 KF Titrino) was employed in the reference procedure. A mechanic stirrer (Tecnal TE 140) was also used.

The indicating device for in situ evaluation of the water content in the samples was based on a conductivity meter, similar to that previously described, ${ }^{12}$ and a comparator. ${ }^{13}$
It was constructed with a series of electronic components: $100 \mathrm{nF}$ and $47 \mu \mathrm{F}$ capacitors, $1 \mathrm{k} \Omega$ to $15 \mathrm{M} \Omega$ resistors, a $10 \mathrm{k} \Omega$ variable resistor, two diodes (1N914) and operational amplifiers (TL084 and LF356N). Two $9 \mathrm{~V}$ batteries were employed as the electric source, and two light emitting diodes (red and green) were used as visual indicators.

The low cost conductometric cell was constructed with a $5.0 \mathrm{~cm}$ long PVC cylinder $(1.2 \mathrm{~cm}$ i.d.) in which two longitudinal holes of $2.8 \mathrm{~mm}$ in diameter and $3.0 \mathrm{~mm}$ separation were made. A hole of $5.0 \mathrm{~mm}$ diameter was made $1.3 \mathrm{~cm}$ from the base of the cylinder, transversally to the $2.8 \mathrm{~mm}$ channels. Two stainless steel nails $(3.0 \mathrm{~mm}$ diameter) were introduced under pressure in the longitudinal channels, and the metallic surface was partially exposed due to the lateral hole. This defines the electrode areas, the distance between the electrodes, and thus the cell constant.

\section{Samples and solutions}

All solutions were prepared with analytical grade chemicals (salts previously dried in a laboratory oven and stored in a desiccator), using anhydrous ethanol (99.9\%) and distilled-deionized water. Ethanol fuel samples were collected in polyethylene vessels from different fuel supply stations in São Paulo City and processed without any treatment.

\section{Procedure}

The effect of salt type and amount was evaluated under a temperature controlled at $25.0 \pm 0.1^{\circ} \mathrm{C}$ by a thermostatic bath. The suspensions were prepared from $10.00 \mathrm{~mL}$ anhydrous ethanol and $0.1,0.5$ or $1.0 \mathrm{~g}$ of $\mathrm{NaCl}, \mathrm{KCl}$ or $\mathrm{CaSO}_{4}$, maintained under constant stirring. The suspensions were spiked with water $(200 \mu \mathrm{L}$ aliquots) up to a total volume of $2.0 \mathrm{~mL}$, and conductometric measurements were carried out after attaining the state of equilibrium (ca. 2 min after each addition). The time required to attain the steady state was evaluated with two ethanol fuel samples after the addition of $\mathrm{NaCl}(100 \mathrm{mg}$ per $10.00 \mathrm{~mL})$ with conductometric measurements (in duplicate) every five min.

Calibration curves were obtained with $10.00 \mathrm{~mL}$ of the reference solutions (from 0 to $16 \% \mathrm{v} / \mathrm{v}_{2} \mathrm{O}$ ) and $100 \mathrm{mg} \mathrm{NaCl}$ placed in $15 \mathrm{~mL}$ graduate polypropylene vessels. The flasks were mechanically stirred for $10 \mathrm{~min}$ before the conductometric measurements. Ethanol fuel samples were similarly processed for water determination.

The reference procedure was based on amperometric Karl Fischer titration. ${ }^{6}$ Six samples of anhydrous ethanol $(10.00 \mathrm{~mL})$ were titrated before and after addition of 50 or 
$100 \mu \mathrm{L} \mathrm{H}_{2} \mathrm{O}$ and the differences between the final volumes were used for standardization of the titrant (Karl Fischer reagent, Merk). Ethanol fuel samples were then titrated (triplicate) for determination of the water content.

\section{Results and Discussion}

\section{Procedure optimization and evaluation of analytical features}

The proposed procedure is based on the differences in solubility of inorganic salts in water and ethanol. When an aqueous ethanolic solution is saturated with an inorganic salt, which is very soluble in water and only slightly soluble in organic solvents, the amount of ions in solution and thus the electric conductivity should correspond to the water content. ${ }^{14,15}$ Different salts (e.g. $\mathrm{NaCl}, \mathrm{KCl}$ and $\mathrm{CaSO}_{4}$ ) were evaluated to achieve this goal, by monitoring the conductivity of a mixture of ethanol and salt as a function of the addition of discrete aliquots of water. A linear response was observed for $\mathrm{NaCl}$ and $\mathrm{KCl}$, the former being selected in view of the more pronounced variation in conductivity with the water content and the lowest variation of solubility with temperature (Table 1). ${ }^{16}$ The selection of $\mathrm{NaCl}$ thus results in a more sensitive and robust procedure, which does not require rigorous temperature control. In addition, $\mathrm{NaCl}$ is more accessible and inexpensive.

Table 1. Solubility of $\mathrm{NaCl}$ and $\mathrm{KCl}$ in water at different temperatures ${ }^{16}$

\begin{tabular}{lccccc}
\hline & \multicolumn{5}{c}{ Temperature / ${ }^{\circ} \mathrm{C}$} \\
\cline { 2 - 6 } & 0 & 10 & 20 & 30 & 40 \\
\hline $\mathrm{NaCl} /\left(\mathrm{g} \mathrm{L}^{-1}\right)$ & 35.6 & 35.7 & 35.8 & 36.0 & 36.3 \\
$\mathrm{KCl} /\left(\mathrm{g} \mathrm{L}^{-1}\right)$ & 27.6 & 31.0 & 34.0 & 37.0 & 40.0 \\
\hline
\end{tabular}

The amount of salt to be used does not require careful control, but needs to be sufficient to saturate the solution. Similar results were obtained when the $\mathrm{NaCl}$ mass was varied from 0.1 to $1.0 \mathrm{~g}$ per $10 \mathrm{~mL}$ ethanol/water solution. The equilibrium condition was achieved after $8 \mathrm{~min}$ of mechanical stirring, as demonstrated for two ethanol fuel samples (Figure 1), and the agitation time was fixed as $10 \mathrm{~min}$. Under this condition, a linear relation was observed between the electric conductivity $(\mathrm{G}, \mu \mathrm{S})$ and the water content $\left(\mathrm{H}_{2} \mathrm{O} \% \mathrm{v} / \mathrm{v}\right)$ up to $16 \%(\mathrm{v} / \mathrm{v})$, described by equation $\mathrm{G}=16.0+36.1 \mathrm{H}_{2} \mathrm{O} \% \mathrm{v} / \mathrm{v}, \mathrm{r}=0.996$. Precision was estimated as $0.6 \%(n=10)$ for an ethanol fuel sample and the limit of detection was $0.05 \%$ (v/v) at $99.7 \%$ confidence level.

An addition-recovery experiment was carried out with five ethanol fuel samples spiked with $200 \mu \mathrm{L}$ of water per $10 \mathrm{~mL}$ (Table 2). The mean recovery was

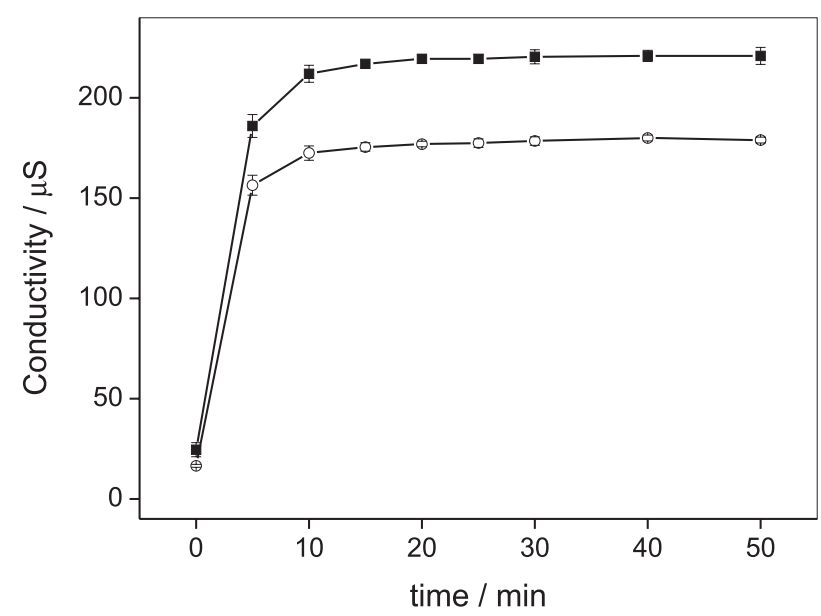

Figure 1. The time effect of mechanical stirring of suspensions prepared from two different ethanol fuel samples after addition of $100 \mathrm{mg} \mathrm{NaCl}$.

estimated at $102.7 \pm 4.7 \%$, indicating an absence of matrix effects in water determination. The effect of ionic species and methanol was evaluated at the threshold limits established by the Brazilian regulations ${ }^{4}\left(4 \mathrm{mg} \mathrm{kg}^{-1}\right.$ sulfate, $1 \mathrm{mg} \mathrm{kg}^{-1}$ chloride, $2 \mathrm{mg} \mathrm{kg}^{-1}$ sodium and $1 \%$ methanol) and neither sample conductivity nor $\mathrm{NaCl}$ solubility were significantly affected (variations of conductivity lower than $5 \%$ ). The results obtained for commercially available ethanol fuel samples from different sources by the proposed procedure agreed with those attained by Karl Fischer titration with amperometric detection ${ }^{6}$ at the $95 \%$ confidence level (Table 3). Excellent correlation between the data was also observed, as described by the equation: $\% \mathrm{H}_{2} \mathrm{O}$ (proposed procedure $)=1.005 \% \mathrm{H}_{2} \mathrm{O}$ (Karl Fischer $)$ $+0.012, r^{2}=0.999$. The proposed procedure is then a simpler and fast alternative for the estimation of water content in ethanol fuel, without using toxic reagents, as in the Karl Fischer titration.

Table 2. Addition-recovery of water in ethanol fuel samples

\begin{tabular}{lccc}
\hline \multirow{3}{*}{ Sample } & \multicolumn{2}{c}{ Water content } & Recovery / \\
\cline { 2 - 3 } & $\begin{array}{c}\text { Without addition / } \\
\%, \mathrm{v} / \mathrm{v}\end{array}$ & $\begin{array}{c}\text { Spiked with } 2 \% \\
\text { v/v } \mathrm{H}_{2} \mathrm{O}\end{array}$ & \\
\hline 1 & 5.35 & 7.33 & 98.8 \\
2 & 5.64 & 7.74 & 105 \\
3 & 6.10 & 8.21 & 105 \\
4 & 5.28 & 7.21 & 96.5 \\
5 & 5.39 & 7.54 & 107 \\
\hline
\end{tabular}

Electronic device for in situ determination of water in ethanol fuel

An electronic device, whose circuit is shown in Figure 2, was developed aiming at the in situ determination 
Table 3. Mean values and uncertainties $(n=3)$ for the determination of water content in ethanol fuel samples

\begin{tabular}{lccc}
\hline \multirow{2}{*}{ Sample } & \multicolumn{2}{c}{ Water content $/ \%, \mathrm{v} / \mathrm{v}$} & \multirow{2}{*}{$\mathrm{Er}^{\mathrm{a}} / \%$} \\
\cline { 2 - 3 } & Proposed procedure & Karl Fischer & \\
\hline A & $6.6 \pm 0.1$ & $6.61 \pm 0.01$ & -0.454 \\
B & $6.8 \pm 0.1$ & $6.88 \pm 0.01$ & -1.16 \\
$\mathrm{C}$ & $6.17 \pm 0.02$ & $6.01 \pm 0.01$ & +2.66 \\
$\mathrm{D}$ & $6.27 \pm 0.01$ & $6.26 \pm 0.01$ & +0.160 \\
E & $6.28 \pm 0.06$ & $6.26 \pm 0.01$ & +0.319 \\
\hline
\end{tabular}

aRelative error.

of water in ethanol fuel. The main goal was to develop a portable system to indicate unconformities in ethanol fuel that could even be operated by nonexperts. The proposed device combines an inexpensive conductivity meter ${ }^{12}$ with a comparator circuit ${ }^{13,17}$ to yield a binary response indicated by coloured light-emitting diodes. A threshold signal is established with an ethanol solution containing the maximum allowable water concentration $(4.9 \% \mathrm{v} / \mathrm{v})$ after saturation with $\mathrm{NaCl}$. Under this condition, the response of the conductivity meter is taken as reference and the variable resistor of the voltage divisor is adjusted to compensate for its response, thus yielding a null output voltage in the comparator which is indicated by both LEDs off. When an ethanol fuel sample saturated with $\mathrm{NaCl}$ is processed in a similar way, unless the sample contains the same amount of water as the reference, the red or green LED will turn on, indicating that conductivity is higher or lower than in the reference (higher or lower water content), respectively. Anomalies in the water content of the fuel can thus be easily detected.

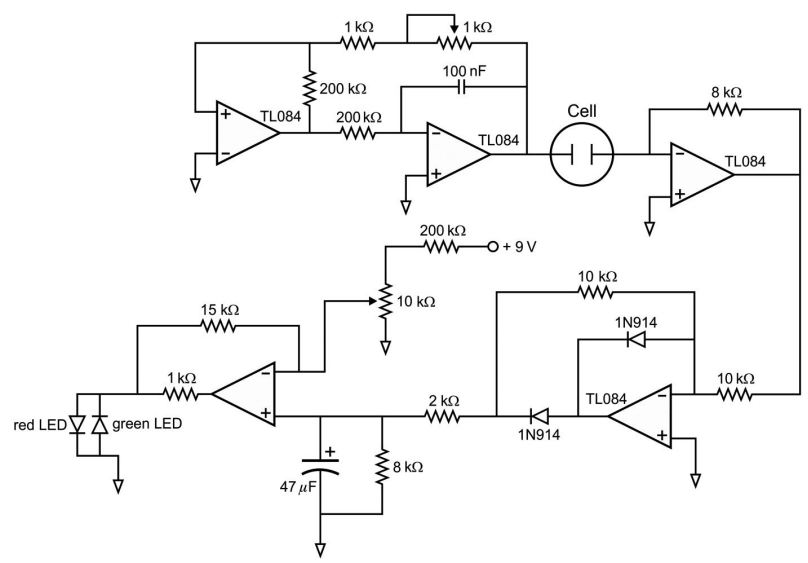

Figure 2. Electronic circuit of the device proposed for in situ detections of unconformities in ethanol fuel.

The conductivity meter used in the instrument is inexpensive, robust and generates an output voltage proportional to the solution conductance. ${ }^{12}$ It is based on an oscillator with triangular wave outputs connected to one of the electrodes, the other being connected to a current-to-voltage converter. The device was powered by two $9 \mathrm{~V}$ batteries, aimed at autonomy for in situ analysis. The conductivity cell was constructed with stainless steel nails as a cheap alternative to replace the usual platinum electrodes. The whole system weights about $300 \mathrm{~g}$, and the materials cost about US\$ 40. An image of the portable system is shown in the Supplementary Information (SI), Figure S1.

The performance of the proposed device was evaluated by analysing 20 commercial ethanol fuel samples spiked with different amounts of water by different analysts. In a blind test, all samples were correctly classified according to the criteria previously described.

\section{Conclusions}

A simple, fast, inexpensive and reagentless procedure was proposed for the determination of the water content in ethanol fuel. In spite of the simplicity, the results were very accurate (in agreement with those obtained by Karl Fischer amperometric titrations). The procedure is robust and does not require strict control of the amount of sodium chloride or the temperature, thus presenting characteristics suitable for in situ analysis. The proposed electronic indicating device can be operated by nonexperts, and it successfully classified samples as regular or anomalous in relation to the water content. The device can be used for screening purposes, thus reducing the number of samples to be analysed in the laboratory and speeding up the adoption of corrective actions.

\section{Supplementary Information}

Supplementary information is available free of charge at http://jbcs.sbq.org.br as PDF file.

\section{Acknowledgements}

The authors acknowledge the fellowships and financial support from the Brazilian agencies Conselho Nacional de Desenvolvimento Científico e Tecnológico (CNPq, CTPETRO proc. No 476185/03-3) and Fundação de Amparo à Pesquisa do Estado de São Paulo (FAPESP).

\section{References}

1. http://www.ethanolrfa.org accessed in November 2012.

2. http://www.mme.gov.br accessed in December 2012.

3. http://www.biodieselbr.com/energia/álcool/etanol.htm accessed in December 2012. 
4. Agência Nacional do Petróleo, Gás Natural e Biocombustíveis, Resolução ANP No. 7, de 9/2/2011 DOU 10.2.2011-Retificada DOU 14.4.2011, http://www.anp.gov.br accessed in December 2012.

5. ABNT NBR 5992: Determination of Specific Mass and Alcoholic Content using Glass Densimeter, ABNT: Rio de Janeiro, Brazil, 2009.

6. Weiland G.; Water determination by Karl Fischer titration, Git Verlag: Darmstadt, Germany, 1987.

7. Liang, C.; Vacha, P.; van der Linden, W. E.; Talanta 1988, 35, 59.

8. Aquino, E. V.; Rohwedder, J. J. R.; Pasquini, C.; Talanta 2007, $71,1288$.

9. Oliveira, W. A.; Pasquini, C.; Talanta 1984, 31, 82.

10. Guchardi, R.; Pasquini, C.; Appl. Spectrosc. 2001, 55, 454.

11. Ribeiro, M. S.; Rocha, F. R. P.; Microchem. J. 2013, 106, 23.

12. Lago, C. L.; Gutz, I. G. R.; Rocha, R. T.; J. Chem. Educ. 1997, 74,572 .
13. Horowitz, P.; Winfield, H.; The Art of Electronics, $2^{\text {nd }}$ ed.; Cambridge University Press: Cambridge, UK, 1995.

14. Lingane J. J.; Eletroanalytical Chemistry, $2^{\text {nd }}$ ed.; Interscience Publishers: New York, USA, 1958.

15. Pezzin, S. H.; Collins, K. E.; Augusto, F.; Determination of water in ethanol by measurements of electric conductance, $13^{\text {th }}$ Annual meeting of the Brazilian Chemical Society, Book of Abstracts, 1990.

16. West, R. C.; Handbook of Chemistry and Physics, $85^{\text {th }}$ ed.; CRC Press: Boca Raton, USA, 2005.

17. Rocha, F. R. P.; Reis, B. F.; J. Chem. Educ. 2000, 77, 258.

Submitted: June 11, 2012

Published online: March 12, 2013

FAPESP has sponsored the publication of this article. 